\title{
Review
}

\section{Further mycotoxin effects from climate change}

\author{
R.R.M. Paterson *, N. Lima \\ IBB-Institute for Biotechnology and Bioengineering, Centre of Biological Engineering, Campus de Gualtar, University of Minho, 4710-057 Braga, Portugal
}

\section{A R T I C L E I N F O}

\section{Article history:}

Received 12 April 2011

Accepted 31 May 2011

\section{Keywords:}

Aspergillus flavus

Fusarium graminearum

Climate change

Aflatoxins

Ochratoxin A

Deoxynivalenol

Africa

North America

\begin{abstract}
A B S T R A C T
Climate change will affect mycotoxins in food. The 2007 Intergovernmental Panel on Climate Change report is reinterpreted herein to account for what may occur with mycotoxins. Warmer weather, heat waves, greater precipitation and drought will have various impacts, depending on which regions of the world and mycotoxin systems are considered. The humidity issues are more complex as some areas will experience drought and others greater precipitation: in vivo data on the effects of moisture on mycotoxins in crops are more ambiguous than those for temperature. In vitro data on fungal growth and mycotoxin production may not relate directly to the situation in the field or post harvest, but are useful for base-line assumptions. The effects of climate in various regions of the world, i.e. Africa, Europe, Asia, Latin America and North America are considered in terms of mycotoxin contamination. Crops introduced to exploit altered climate may be subject to fewer mycotoxin producing fungi (the "Parasites Lost" phenomenon). Increased mycotoxins and UV radiation may cause fungi to mutate on crops and produce different mycotoxins. Whereas there is relevant information on aflatoxins, deoxynivalenol, and ochratoxin A, more mycotoxins require to be considered: Data on patulin are missing. The current paper considers uniquely ergot alkaloids. Amelioration strategies are provided. There is considerable urgency in the need to address these issues.
\end{abstract}

(c) 2011 Elsevier Ltd. All rights reserved.

\section{Contents}

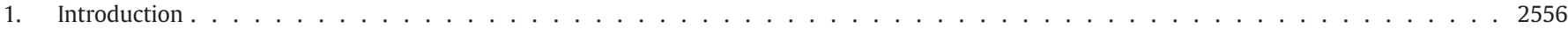

2. Predictions concerning temperature on pre-harvest crops . . . . . . . . . . . . . . . . . . . . . . . . 2557

2.1. A warmer planet is "virtually certain" $($ IPCC, 2007) . . . . . . . . . . . . . . . . . . . . . . . . . . . 2557

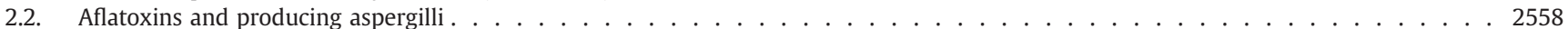

2.3. Deoxynivalenol, fumonisins and fusaria . . . . . . . . . . . . . . . . . . . . . . . . . . 2559

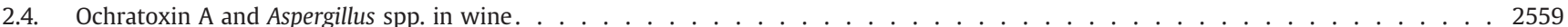

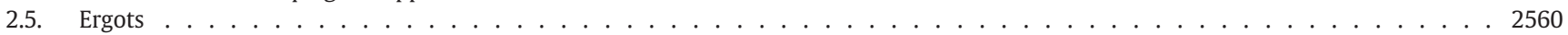

2.6. General

3. Predictions concerning precipitation on pre harvest crops . . . . . . . . . . . . . . . . . . . . . . . 2560

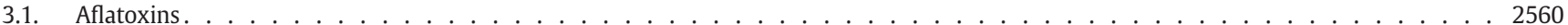

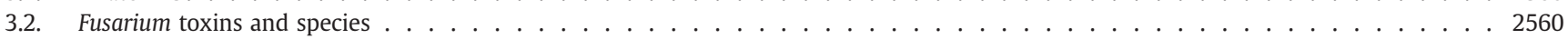

3.3. Ochratoxin A and grapes. . . . . . . . . . . . . . . . . . . . . . . . . . . . 2560

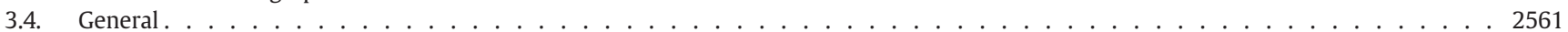

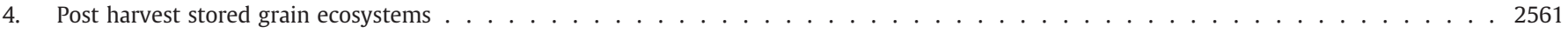

5. Carbon dioxide change and mycotoxin production . . . . . . . . . . . . . . . . . . . . . . . . . . . . . . 2561

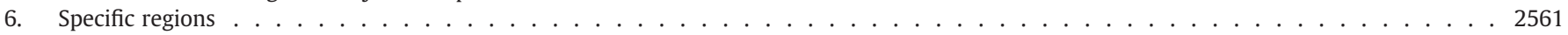

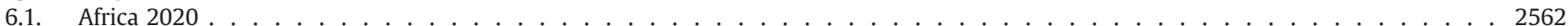

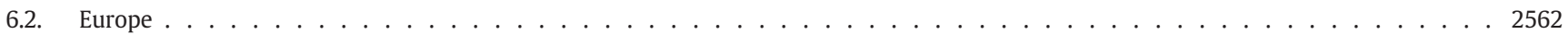

6.3. Australia/New Zealand $2030 \ldots \ldots 2562$

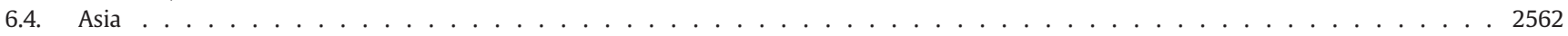

6.5. Latin America $2050 \ldots \ldots \ldots \ldots$

6.6. North America . . . . . . . . . . . . . . . . . . . . . . . . . . . . . . . . . . . . . . . . . . . . . . . . . . . . . . . . 2563

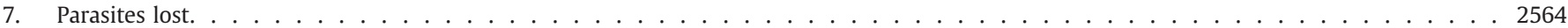

* Corresponding author.

E-mail address: russell.paterson@deb.uminho.pt (R.R.M. Paterson). 
8. Toxigenic fungi, biosynthesis rates and climate models . . . . . . . . . . . . . . . . . . . . . . 2564

9. The climate change mycotoxin cycle . . . . . . . . . . . . . . . . . . . . . . . . . . . . . . . . . . 2564

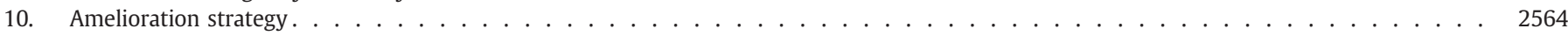

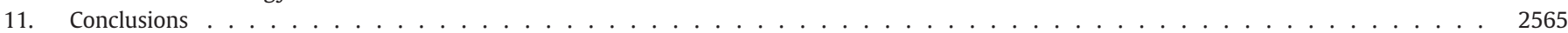

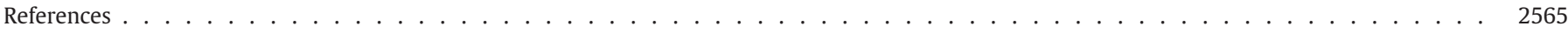

\section{Introduction}

Climate change (CC) (IPCC, 2007) will affect mycotoxins in food. Related to the following discussion it is necessary to point out that more than 1 billion people are living currently in malnutrition and hunger (Tirado, Cohen, Aberman, Meerman, \& Thompson, 2010). Human activity is causing the weather phenomenon, hence we are living in the Anthropocene epoch whereby the environment is being changed (Crutzen \& Stoermer, 2000; Pringle, Barron, Sartor, \& Wares, 2011). Concentrations of methane, carbon dioxide, nitrous oxide and chlorofluorocarbons in the atmosphere are increasing, resulting in environmental warming, greater precipitation, or drought. "Climate changes or extreme climatic events are already part of our everyday life and can be seen more and more frequently. Thus the subject of "climate change" is currently of unrivalled importance and discussions of its impact on the future of mankind are becoming more and more common in the various branches of society." (Sant'Ana, 2010). Unfortunately, greater effort has not been made to slow CC particularly by cutting industrial emissions.

There is a lack of information on CC and food science, implying an even greater deficit with mycotoxins. Many data indicate that plant epidemics are influenced climatically (Paterson, in press; Paterson \& Lima, 2010a). Changing temperature and rainfall may threaten food security (Miraglia et al., 2009; Miraglia, de Santis, \& Brera, 2008; Tirado, Clarke, Jaykus, McQuatters-Gollop, \& Frank, 2010; van der Fels-Klerx et al., 2009) and will have a negative impact especially in developing countries.

Weather-based plant disease forecasts relate to (a) CC models, and (b) predicting the effects of CC on whether, where and which mycotoxins will be changed. Mycotoxins depend on (a) climate (Table 1), (b) plant- and storage-associated problems (Table 1), and (c) non-infectious factors (e.g. bioavailability of (micro) nutrients, insect damage and other pests attack) that are driven by weather (Magan, Hope, Cairns, \& Aldred, 2003), although the other factors cannot be ignored or emphasised selectively (see Magan et al., 2011; Paterson, in press). Insect and pest attack, pesticides, soil, fertilisers and trace elements also require to be studied further but largely fall outside the scope of the current review. The issue offers a complicated, multifaceted and interrelated scenario which could impair seriously the availability of food and feed in developing countries in particular (Miraglia et al., 2009; Tirado, Clarke, et al., 2010). Hence, crop yields will decrease or increase with corresponding mycotoxin changes as CC occurs.

The current authors consider how mycotoxins in food (and water) will be affected by building on the reviews of Paterson and Lima (2010a) and Magan et al. (2011)whilst presenting new concepts. Paterson and Lima (2010b,c,d) have influenced greatly the concepts presented herein. Climatic alterations have a high impact on plantpathogen interactions (Jeger \& Pautasso, 2008) and useful mycotoxin models for predicting contamination is a key component for addressing the issue (van der Fels-Klerx et al., 2009). The effects of CC on mycotoxins in the preharvest situation could be from hostsfungi interactions, the fungi, or the hosts: epidemic severity may be decreased by CC effects on host-pathogen/environmental interactions (Chakraborty et al., 1998).

Mycotoxins may be lower if the temperature becomes too high for relevant fungi to grow, or produce mycotoxins. Some of the conditions which have been demonstrated in vivo to result in higher and lower mycotoxins are provided in Table 1 . Table 2 lists the optima for production of mycotoxins and growth of the associated fungi from in vitro studies: Table 3 demonstrates typical lower moisture limit for fungi on seeds of important crops in vitro. Further important predictions can be made by considering all these data in a unifying manner such as presented herein. In vivo data that "integrate the environment" (Paterson \& Lima, 2010a) (Table 1) are preferable generally to in vitro work on isolated fungi and unrepresentative crop substrates (Tables 2 and 3). The in vitro work cannot investigate all the parameters mentioned above that affect mycotoxins in crops unlike in vivo research. For example, Fusarium graminearum DNA and deoxynivalenol could be measured in wheat samples stored for long periods (Shaw, Bearchell, Fitt, \& Fraaije, 2008), thus providing long term information about the effect of CC in crops grown in Nature.

Furthermore, species extinction is predicted because of CC (IPCC, 2007) and fungi will be susceptible to this threat (Pringle et al., 2011), including the mycotoxigenic representatives (Paterson \& Lima, 2010a). Fungal conidia are not so resistant as might be expected and of course the asexual forms, which occur in the primary mycotoxin producing fungi, do not produce hardy sexual spores. For example, the Aspergillus carbonarius conidia used in Leong, Hocking, and Scott (2006) were killed in a few hours at $37^{\circ} \mathrm{C}$. CC may lead to an expanding range of crop pests and altered transmission dynamics of insects, pests, and plant diseases, which will exacerbate yield reduction and impair food safety (Rosenzweig, Iglesias, Yang, Epstein, \& Chivian, 2001). It is undeniable that these will affect mycotoxins in manners that are to some extent predictable, and it is worthwhile listing, for the record, areas that might at first appear obvious. The mycotoxins that pose the greatest potential risk are aflatoxins, trichothecenes, fumonisins, zearalenone, ochratoxin A, ergot alkaloids (CAST, 2003) and patulin (see Magan et al., 2011). For example, maize has become a staple for many millions in warm regions throughout Africa, Asia, and the Americas with vulnerabilities exemplified by recent lethal aflatoxicoses in Kenya (Lewis et al., 2005). The fact that ergot alkaloids have not been considered before in terms of CC is a considerable omission: Claviceps spp. produces these toxic alkaloids (CAST, 2003). Ergot "bodies" contain toxic amounts of alkaloids and lead to the disease of ergotism in humans and other animals which consume them. Outbreaks of Claviceps africana and/or Claviceps sorghi in North America and Australia have become major concerns (Tables 1).

Paterson and Lima (2010a) asked, "How will climate change affect mycotoxins?" Magan et al. (2011) claimed that Paterson and Lima (2010a) contained omission in relation to (a) the effects of $\mathrm{CO}_{2}$ levels and temperature/water availability, (b) chemical and other control treatments and (c) integration of molecular and ecological information. However, Paterson (in press) pointed out that the areas were not omitted but were presented with different emphases. $\mathrm{CO}_{2}$ levels were not discussed in terms of direct effects as the literature only provides information on unrealistically high concentrations, and overall, the issues were addressed appropriately in Paterson and Lima (2010a).

There will be two predominant effects on crops due to CC: more may be produced in currently cool or cold regions (e.g. parts of Northern Europe), and fewer will be harvested in currently hot regions (e.g. many areas within Africa) (see Section 6.1). These basic facts will affect mycotoxins in predictable ways:

Scenario 1 . There is likely to be an increase in total mycotoxins because more crops are produced within a region 
Table 1

Summary of more and less dangerous conditions for crops in terms of mycotoxin contamination which can be employed to predict consequences of climate change.

\begin{tabular}{|c|c|c|c|}
\hline Mycotoxin & Increased danger & Decreased danger & References \\
\hline Aflatoxin preharvest & $\begin{array}{l}\text { Heat (e.g. }>25{ }^{\circ} \mathrm{C} \text { ) and drought dangerous. But } \\
\text { humidity dangerous for cottonseeds. Rain at } \\
\text { dry-down dangerous. }\end{array}$ & Cool temperatures safe $\left(\right.$ e.g. $<20^{\circ} \mathrm{C}$ ) & $\begin{array}{l}\text { Cotty and Jaime-Garcia (2007); Shearer et al. } \\
\text { (1992); Sanders et al. (1984); Schmitt and } \\
\text { Hurburgh (1989); Jaime-Garcia and Cotty }\end{array}$ \\
\hline Postharvest & $\begin{array}{l}\text { Rain at harvest delaying dry-down and rain on } \\
\text { peanut windrows. }\end{array}$ & $\begin{array}{l}\text { Corollary is, dry weather helps dry down and } \\
\text { storage. }\end{array}$ & $\begin{array}{l}\text { (2003); Cole et al. (1989). Bock et al. (2004); } \\
\text { Cardwell and Cotty (2002); Miraglia et al. } \\
\text { (2009); Magan et al. (2011); Lewis et al. (2005); } \\
\text { Boyd \& Cotty (2001); Wilson and Payne (1994); } \\
\text { Iqbal et al. (2011). }\end{array}$ \\
\hline Deoxynivalenol & $\begin{array}{l}\text { Warm weather dangerous but higher than } 32{ }^{\circ} \mathrm{C} \\
\text { safer. Humidity/rain ambiguous, but generally } \\
\text { high levels more dangerous }\end{array}$ & $\begin{array}{l}\mathrm{Cool}<10{ }^{\circ} \mathrm{C} \text { and hot weather }>32{ }^{\circ} \mathrm{C} \text { safer. Rain } \\
\text { ambiguous (i.e. low or high can be dangerous) }\end{array}$ & $\begin{array}{l}\text { Miraglia et al. (2009); Magan et al. (2011); } \\
\text { Isebaert et al. (2009); Waalwijk et al. (2003); } \\
\text { Jennings et al. (2004); Xu et al. (2005). }\end{array}$ \\
\hline Fumonisins & $\begin{array}{l}\text { Warm dangerous. Dry at grain fill and rain/ } \\
\text { humidity dangerous at other times. }\end{array}$ & $\begin{array}{l}\text { Corollary is that cool temperatures and low rain } \\
\text { are safer, apart from at grain fill. }\end{array}$ & $\begin{array}{l}\text { Schaafsma and Hooker (2007); de la Campa } \\
\text { et al. (2005); Munkvold and Desjardins (1997). }\end{array}$ \\
\hline Ochratoxin A (grapes) & $\begin{array}{l}\text { High temperate dangerous (towards } 30^{\circ} \mathrm{C} \text { ). } \\
\text { High humidity more generally dangerous, but } \\
\text { dry conditions problem on occasions } \\
\text { (ambiguous). }\end{array}$ & $<21^{\circ} \mathrm{C}$ at "berry" is safe. Moisture ambiguous. & $\begin{array}{l}\text { Magan et al. (2011); Battilani et al. (2006); Bellí } \\
\text { et al. (2005); Tjamos et al. (2006); Clouvel et al. } \\
\text { (2008); Bellí et al. (2007). }\end{array}$ \\
\hline Ergot (sorghum) & $\begin{array}{l}\text { Ergot }<15^{\circ} \mathrm{C} \text {. Optimum day mean } 25^{\circ} \mathrm{C} \text {, } \\
\text { humidity } 96 \% \text {, Max } 28{ }^{\circ} \mathrm{C} \text {, night humidity } 86 \% \text {. }\end{array}$ & Sowing June 15 to July 14 . & $\begin{array}{l}\text { Montes-Belmont, Méndez-Ramírez, and Flores- } \\
\text { Moctezuma (2002) }\end{array}$ \\
\hline
\end{tabular}

Table 2

Optimal temperature for mycotoxin production and growth in vitro (the numbers in the table are in ${ }^{\circ} \mathrm{C}$ ) (Sanchis \& Magan, 2004).

\begin{tabular}{|c|c|c|c|c|c|c|c|c|c|}
\hline \multirow[t]{2}{*}{ Fungus species } & \multicolumn{8}{|c|}{ Mycotoxins } & \multirow[t]{2}{*}{ Fungus growth } \\
\hline & $\begin{array}{l}\text { Alternaria } \\
\text { toxins }\end{array}$ & $\begin{array}{l}\text { Tenuazonic } \\
\text { acid }\end{array}$ & Aflatoxins & Fumonisins & Deoxynivalenol & Ochratoxin A & Patulin & $\begin{array}{l}\text { Ergot } \\
\text { alkaloids }\end{array}$ & \\
\hline Alternaria alternata & 25 & & & & & & & & 23 \\
\hline Alternaria tenuissima & & 20 & & & & & & & \\
\hline Aspergillus flavus & & & 33 & & & & & & 35 \\
\hline F. verticillioides $F$. proliferatum & & & & $15-30$ & & & & & 30 \\
\hline F. graminearum & & & & & 30 & & & & $20-22$ \\
\hline F. culmorum & & & & & 26 & & & & $20-25$ \\
\hline A. ochraceus & & & & & & $25-30$ & & & 30 \\
\hline Penicillium verrucosum & & & & & & 25 & & & 26 \\
\hline P. expansum & & & & & & & $10^{\mathrm{a}}$ & & $25-30$ \\
\hline A. carbonarius & & & & & & $30{ }^{\circ} \mathrm{C}$ higher than at $20^{\circ} \mathrm{C}$. & & & $25-30^{\circ} \mathrm{C}$. Greek strains \\
\hline & & & & & & Greek strains $15-20^{\circ} \mathrm{C}$. & & & $30-35^{\circ} \mathrm{C}$ \\
\hline Claviceps sp. & & & & & & & & $23-26^{\circ} \mathrm{C}$ & 30 \\
\hline
\end{tabular}

a Baert et al. (2007).

(Table 4). Hence, there are (a) three situations where the concentrations could be greater, (b) one equal situation, and (c) one lower scenario (Table 4). The situation that allows for the concentration to be less would have to be quite specific (e.g. introduction of a genetically modified (GM) crop) and so, overall, the concentrations are likely to be greater.

Scenario 2. A decrease is likely in total mycotoxins because fewer crops are produced within a region (Table 4). There are (a) three situations where the concentrations are lower, (b) one equal situation and (c) one higher scenario (Table 4). Hence, the concentrations are likely to be lower, although conditions such as drought or heat stress may increase levels from damage to crops and allowing ingress of fungi. The point is, there is a trend towards

Table 3

Lower moisture limits for growth of Aspergillus spp. and Penicillium spp. on seeds of crops (Paterson \& Lima, 2010a).

\begin{tabular}{lccc}
\hline \multirow{2}{*}{ Plant } & \multicolumn{3}{c}{ Moisture content of grain (\%) } \\
\cline { 2 - 4 } & A. ochraceus & A. flavus & Penicillium spp. \\
\hline Starch cereal grains & $15.5-16.0$ & $17.0-18.0$ & $16.5-20.0$ \\
Soybeans & $14.5-15.0$ & $17.0-17.5$ & $17.0-20.0$ \\
Sunflower, safflower, peanuts and copra & $9.0-9.5$ & $10.0-10.5$ & $10.0-15.0$ \\
\hline
\end{tabular}

lower mycotoxins if the amount of crops produced are reduced and vice versa.

The intergovernmental Panel on Climate Change (IPCC, 2007) report is influential although was not discussed in Paterson and Lima (2010a). The current paper re-interprets the predictions made in the report in terms of mycotoxin contamination. The physiology of growth and mycotoxin production of the fungi are considered further especially in relation to the predicted alterations in weather.

\section{Predictions concerning temperature on pre-harvest crops}

\subsection{A warmer planet is "virtually certain" (IPCC, 2007)}

IPCC (2007) states that a warmer planet is "virtually certain" and warm spells or heat waves are "very likely". Impacts on agriculture and food safety will vary for different geographical regions and profound impacts on agriculture will occur (e.g. alterations in arable land and crop yields, variations in the seasons, changes in soil quality). Increases in losses of soil minerals, variation in their bioavailability and alterations in soil microorganism ecosystems are all mentioned (IPCC, 2007). The report states that temperature will rise by approximately $4{ }^{\circ} \mathrm{C}$ in 100 years (Fig. 1). This may affect mycotoxin concentrations as fungi with higher temperature optima for growth and mycotoxin production will dominate in regions with currently cooler climates, or become less prevalent as the temperatures become too high in region where the temperature is already hot. Interestingly, 
Table 4

The likely effects of greater and reduced crop production on mycotoxins from climate change.

\begin{tabular}{|c|c|c|c|}
\hline Scenario & $\begin{array}{l}\text { Hypothetical crop production and mycotoxin } \\
\text { concentration currently }\end{array}$ & Climate change effect & Mycotoxin quality of crop produced under climate change is: \\
\hline $\begin{array}{l}\text { 1. More crops produced and more total } \\
\text { mycotoxins likely. }\end{array}$ & $\begin{array}{l}1 \mathrm{~kg} \text { of crop with total mycotoxin } \\
\text { concentration } 1 \mu \mathrm{g} .\end{array}$ & $\begin{array}{l}\text { Assume } 2 \mathrm{~kg} \text { of crop } \\
\text { is produced. }\end{array}$ & $\begin{array}{l}\text { (A) the same: this gives } 2 \mu \mathrm{g} \text { of total mycotoxins, i.e. more } \\
\text { mycotoxins than before; } \\
\text { (B) worse: this gives more than } 2 \mu \mathrm{g} \text { of total mycotoxins, i.e. } \\
\text { more mycotoxins; } \\
\text { (C) better: three possible situations result:- } \\
\text { i. A concentration greater than } 1 \text {, but less than } 2 \mu \mathrm{g} \text { of total } \\
\text { mycotoxin, i.e. more mycotoxin. } \\
\text { ii. A concentration of } 1 \mu \mathrm{g} \text {, i.e. the same concentration of } \\
\text { mycotoxins. } \\
\text { iii. A concentration less than } 1 \mu \mathrm{g} \text {, i.e. lower mycotoxin } \\
\text { concentrations. }\end{array}$ \\
\hline $\begin{array}{l}\text { 2. Fewer crops are produced and fewer } \\
\text { total mycotoxins likely }\end{array}$ & $\begin{array}{l}2 \mathrm{~kg} \text { of a crop is produced with a total } \\
\text { mycotoxin concentration of } 2 \mu \mathrm{g}\end{array}$ & $\begin{array}{l}\text { Assume } 1 \mathrm{~kg} \text { of crop } \\
\text { is produced. }\end{array}$ & $\begin{array}{l}\text { (A) the same: This gives } 1 \mu \mathrm{g} \text { of total mycotoxins, i.e. lower } \\
\text { mycotoxin concetrations than before. } \\
\text { (B) better: This gives less than } 1 \mu \mathrm{g} \text { of total mycotoxins, i.e. } \\
\text { lower mycotoxins. } \\
\text { (C) worse: Three possible situations result:- } \\
\text { i. A concentration greater than } 1 \text {, but less than } 2 \mu \mathrm{g} \text { of } \\
\text { mycotoxin, i.e. lower mycotoxins. } \\
\text { ii. A concentration of } 2 \mu \mathrm{g} \text {, i.e. the same concentration of } \\
\text { mycotoxins. } \\
\text { iii. A concentration more than } 2 \mu \text { g, i.e. more mycotoxins. }\end{array}$ \\
\hline
\end{tabular}

Table 1 indicates that temperature is more predictable in terms of the effect on mycotoxin problems than moisture effects.

More crops/greater yields will occur in currently cool regions and fewer crops/yields will occur in currently warm regions (IPCC, 2007). This corresponds to scenarios 1 and 2 respectively as discussed above and Table 4. If crops increase it will be important to consider increasing the amount of mycotoxin analyses proportionately. Where more crops/greater yields will occur from CC in currently cool regions, an increase in the total mass of mycotoxins will tend to occur simply because there are more crops (Table 4). The overall quality of the crops may be worse than before in terms of mycotoxins per unit weight of crop because, for example, aflatoxins may increase as the temperature increases towards the optima for the producing fungi. Finally, the currently cool regions will experience worsening storage conditions as the temperature increase to those compatible with increased fungal growth.

Fewer crops/yields will occur from CC in some currently warm regions. This will lead to a decrease in the total mass of mycotoxins simply because there are fewer crops (i.e. scenario 2 (see Section 1) and Table 4). However, it is possible that the crops produced will be of lower quality due to the stress effects of CC and may contain more mycotoxins per unit weight of crops. Finally, the new hot and dry conditions in some regions will lead to good storage conditions - a potential advantage of CC. This is because the hot and dry conditions will assist in maintaining the crop in a dry condition unsuitable for fungal growth and mycotoxin production.

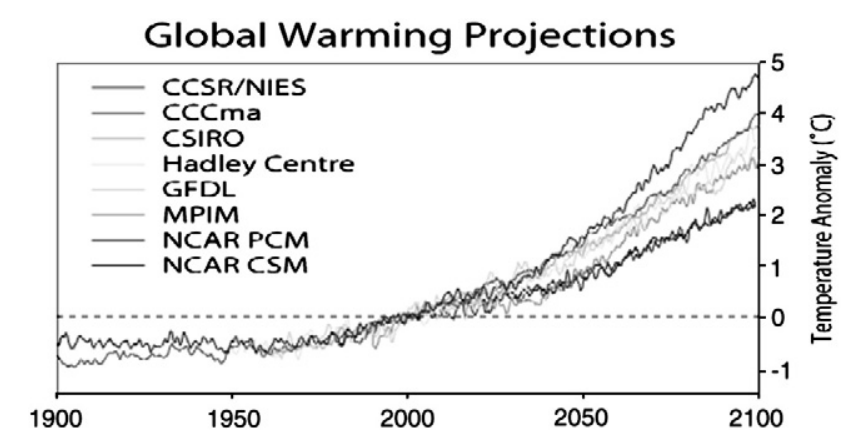

Fig. 1. Change in temperature due to climate change according to the IPCC (2007) report.
Furthermore, some regions may become suitable for growing novel crops and others unsuitable for existing ones. More insect pests will occur at higher temperatures (IPCC, 2007) by which mycotoxigenic fungi are spread (Beniston \& Diaz, 2004; Tirado, Clarke, et al., 2010) and more insects may increase insect-feeding birds perhaps resulting in more bird damage to crops: The ecological implications of $\mathrm{CC}$ are indeed complex.

\subsection{Aflatoxins and producing aspergilli}

The conditions which are more "dangerous" or "safer" for aflatoxin are presented in Table 1. However, developing crops are very resistant frequently to infection by Aspergillus flavus although high daily temperature minima lead to "poisoned crops" (Cotty \& Jaime-Garcia, 2007). It is worth pointing out that changes in climate may lead to acute aflatoxicosis and human deaths even in modern times (Lewis et al., 2005). Heat (e.g. $>25^{\circ} \mathrm{C}$ ) and drought are dangerous, although humidity is problematic for cottonseed. Furthermore, rain at drydown is detrimental especially for further storage. Cool temperatures (e.g. $<20^{\circ} \mathrm{C}$ ) can be considered to be safer for aflatoxin contamination and aflatoxin may become more common in currently temperate climates in Western Europe as temperature increase (Miraglia et al., 2009). A particularly useful example of in vivo studies was provided by Iqbal et al. (2011) on chilies produced in summer or winter in Pakistan, where the chilies produced in summer had significantly higher aflatoxin contamination. Studying crops produced in different seasons within a year is recommended for determining the effects of climate.

Fungal infection occurs with drought and temperature increases (Sanders et al., 1984; Schmitt \& Hurburgh, 1989); interestingly IPCC (2007) lists regions where these events will occur. Aflatoxin fungi are native to tropical, warm, arid and semi-arid regions. It is relevant to mention that changes in climate result in large alterations in the quantity of aflatoxin producing fungi (Bock et al., 2004; Shearer et al., 1992; Table 1). Indeed much of the organic matter in soils is colonised by aflatoxigenic fungi in such regions (Boyd \& Cotty, 2001) and hence, this colonisation may occur when temperate regions become warmer (Miraglia et al., 2009). Aflatoxin producers are associated with hot, dry "agroecozones" in Africa with latitudinal shifts in climate influencing fungal structure (Cardwell \& Cotty, 2002).

There exists a wide-range of temperature optima for growth from 35 to $21{ }^{\circ} \mathrm{C}$ for isolated $A$. flavus and $F$. graminearum strains 
respectively (Table 2) with most other fungi falling between these values. Some fungi will dominate others as CC occurs on this basis. For example, A. flavus will tend to outcompete other fungi with lower optima, although it may not survive in already hot climates (Iqbal et al., 2011; Paterson \& Lima, 2010a). A. flavus was isolated more frequently than Aspergillus ochraceus from Brazil nuts and pepper from Brazil (Freire, Kozakiewicz, \& Paterson, 2000): it would be unlikely that $A$. ochraceus would dominate A. flavus in 100 years on the basis of optimal growth temperatures (Table 2) making aflatoxin to remain the major concern. In Northern Portugal, A. carbonarius dominated the mycotoxigenic fungi from grapes (Serra, Lourenço, Alípio, \& Venâncio, 2006; Serra, Mendonca, \& Venancio, 2006). A. flavus was present in lower amounts and Penicillium expansum was at low concentrations. In 100 years, A. flavus may outcompete A. carbonarius with aflatoxin become a greater risk than ochratoxin A. Equally, the conditions may become too hot for $P$. expansum and hence reducing the threat from patulin. Furthermore, at $30^{\circ} \mathrm{C}$ the lag phases and growth rates of $A$. ochraceus and Aspergillus parasiticus were similar (Garcia, Ramos, Sanchis, \& Marín, 2011). At $37^{\circ} \mathrm{C}$ the $A$. ochraceus lag phase increased dramatically compared to $A$. parasiticus, and growth rates were lower for $A$. ochraceus. This indicates that the two species would compete at $30^{\circ} \mathrm{C}$ but then $A$. parasiticus may dominate with aflatoxin becoming a greater problem, although the authors warn of the risks of using models as substitutes for the situations in the field. On this basis, A. flavus will not be dominated by Alternaria, Fusarium, Aspergillus (other species), and Penicillium species and aflatoxin will not be supplanted by alternariol, deoxynivalenol, fumonisins, and ochratoxin A as the optimum temperatures for mycotoxin production are usually only slightly different (Table 2). Equally, aflatoxin will not be supplanted by (a) ochratoxin in peanuts, corn, wheat, cheese, (b) deoxynivalenol in corn and wheat and (c) fumonisin in corn where the mycotoxins co-occur (CAST, 2003).

In northern Europe the trend towards higher temperatures (IPCC, 2007; Miraglia et al., 2009) may lead to more crops being produced and increasing "higher temperature mycotoxins" e.g. aflatoxin, compared to deoxynivalenol. Heat waves (Beniston \& Diaz, 2004) will result in fewer crops (scenario 2) and will make them liable to greater concentrations of mycotoxins. There may be a replacement of fungi with lower optima, such as $A$. ochraceus replacing Fusarium spp. and ochratoxin A becoming increasingly problematic; other combinations can be predicted from Table 2 for other fungal/mycotoxin systems. For example, A. flavus, $F$. graminearum and Fusarium verticillioides grow on maize and the dominant species is determined by meteorological conditions (Magan et al., 2011; Miraglia et al., 2009). Hot and dry weather caused an outbreak in 2003 of A. flavus (which is xerophilic) resulting in aflatoxin in maize which was previously uncommon in Europe, including the south (Table 1). F. verticillioides is the most common species in the south which grows optimally at $25-30{ }^{\circ} \mathrm{C}$ and produces fumonisins. Furthermore, significant deoxynivalenol levels were only detected before 1995 in Italy (Miraglia et al., 2009). There were very hot and dry episodes in 2003-2004 in northern Italy where maize is a key crop and A. flavus became a significant problem because of the very dry conditions in those years (Giorni, Battilani, \& Magan, 2008). They describe how isolated strains were able to colonise ripening maize rapidly and produce aflatoxin and "sterigmatocystin". However, there were no data about the isolated strains colonising ripening maize (although the strains were from maize) and no information on sterigmatocystin production was presented. Cyclopiazonic acid and aflatoxin were detected, although some strains did not produce detectable aflatoxin. In vivo factors affecting mycotoxins in crops are provided in Table 1 which are potentially more relevant than the in vitro. Finally, there is awareness of A. flavus and aflatoxin as weapons (Paterson \& Lima, 2010e) and CC may make some regions more susceptible to an attack than previously considered possible.

\subsection{Deoxynivalenol, fumonisins and fusaria}

Warm weather is dangerous in terms of increased deoxynivalenol production on crops (Table 1 ), although higher than $32{ }^{\circ} \mathrm{C}$ is safer and these data corresponds well to the in vitro data concerning growth optima which indicate that this temperature is greater than the optimum (Table 2). Humidity and rain provide ambiguous information on contamination, but generally, high levels of rain are more dangerous, whereas safer weather involves cool temperatures of $<10^{\circ} \mathrm{C}$. Forecasting mycotoxin concentrations have provided the basis for decisions for reducing, or re-directing high concentrations of mycotoxins from the food chain. The predictive tool 'DON cast' (Hooker, Schaafsma, \& Tamburic-Ilincic, 2002) for ameliorating CC problems (Paterson \& Lima, 2010a) has been discussed, although a simpler system only using temperature and precipitation may also be useful.

Fusarium in wheat can be determined by (i) incidence, disease symptoms, or presence of "scabby" kernels at harvest and (ii) mycotoxins in mature grain at harvest. However, significant variation in toxin concentrations were observed depending on environmental and agronomic variables (Paul, Lipps, \& Madden, 2006), making predictions unreliable that employ models from visible disease symptoms. Data from Argentina and the Philippines were produced to determine the effects of climate, insect damage, and hybrid on fumonisin concentrations in grain corn at harvest (de la Campa et al., 2005). The range of concentrations was much higher than that of a similar investigation in Canada (Paterson \& Lima, 2010a). Mild temperatures and rain during maize growth is conducive to $F$. graminearum and deoxynivalenol which is relevant to central Europe. Surveys indicated an increase in F. graminearum over Fusarium culmorum as the former species has a higher temperature optimum (Jennings et al., 2004; Waalwijk et al., 2003) and this relates to predicted higher temperatures. However, the predominant risk is the same mycotoxin, deoxynivalenol (Table 1 ), making this observation less significant. Finally, Isebaert et al. (2009) demonstrated that $F$. graminearum was predominant due to the effect of warm weather in growing season 2004-2005, whilst F. culmorum was dominant in 2001-2002 where a low average July temperature of $17.4{ }^{\circ} \mathrm{C}$ occurred.

\subsection{Ochratoxin A and Aspergillus spp. in wine}

The conditions which favour ochratoxin $\mathrm{A}$ in wine are outlined in Table 1: High temperatures reaching $30^{\circ} \mathrm{C}$ and increased humidity are dangerous, although dry condition cause problems occasionally. Temperatures lower than $21^{\circ} \mathrm{C}$ are safer, with the effect of moisture being more ambiguous. It is noticeable that humidity levels tend to be more contradictory than temperatures in terms of mycotoxin levels in general. There are predictions of wine production moving north in Europe because of CC (Paterson and Lima, 2010a) and samples from 11 vineyards from 4 winemaking regions in the North and South of Portugal were assessed for ochratoxin A and fungi (Serra, Lourenço, et al., 2006; Serra, Mendonca, \& Venancio, 2006). Significant differences were observed in ochratoxin A from grapes between 2002 and 2003 which may have been related to temperature: Isolation of ochratoxin A producing fungi were insignificantly different between 2001 and 2003. Small increases in temperature will bring the grapes into the ranges where critical levels are reached in French and Spanish wine (Paterson \& Lima, 2010a). Delineating the effect of $a_{\mathrm{w}}$ and temperature on A. carbonarius conidia may aid in understanding the incidence of this ochratoxin A-producing species in vineyard soils and grapes, contributing to CC modelling (Miraglia et al., 2009). The effects on isolated fungi are discussed in more detail in Paterson and Lima (2010a): Fungi associated with grapes and their ability to produce ochratoxin A on synthetic media were investigated (Belli et al., 2005) and extrapolated to the in vivo situation. A positive correlation between the number of black aspergilli found in grapes and the temperature in the field was found. However, the term "black aspergilli" is unspecific in terms of ochratoxin production. 


\subsection{Ergots}

A general description of ergot formation is provided here because this form of contamination has not been addressed before in terms of CC. The early stage of infection in the field involves production of a sweet liquid suspension of asexual spores that are transferred by insects (hence susceptible to CC) across grass florets. The growing mycelium infects florets close to pollination, grows into the ovary, and surrounds the female florets. The fungus produces a resting structure termed sclerotia, or ergot which fall from the plant, overwinter in the ground, and then fruit sexually the following spring when grass hosts flower (Table 1).

Again, some basic information is provided to assist with future deliberations in this area. An increase in (a) biomass of Claviceps purpurae and (b) ergot alkaloids occurred simultaneously in artificial culture: The fungus grew well at $28{ }^{\circ} \mathrm{C}$ in solid culture and good production of ergot alkaloids and growth was observed at $24{ }^{\circ} \mathrm{C}$ in liquid culture (Amici, Minghetti, Scotti, Spalla, \& Tognoli, 1969). The sclerotia were resistant greatly to high temperatures and lost the ability to germinate at 200,300 , and $400{ }^{\circ} \mathrm{C}$ for 116,48 , and $15 \mathrm{~s}$ respectively, whereas $100{ }^{\circ} \mathrm{C}$ and $50{ }^{\circ} \mathrm{C}$ for $240 \mathrm{~s}$ reduced germination slightly (Johnston, Golob, Sitton, \& Schultz, 1996). Ergot alkaloid fermentations are carried out at $20-30{ }^{\circ} \mathrm{C}$ with an optimal between $23-26{ }^{\circ} \mathrm{C}$ and a $\mathrm{pH}$ range of $4.6-6.3$ was also employed with an optimum at 5.2-5.8 (Řeháček, 1991). Montes-Belmont et al. (2002) indicated ergot levels varied between the years 1998 and 2000 in Mexico, with 2000 providing the highest amounts and these variations related to weather conditions.

\subsection{General}

Finally, interacting conditions of water/temperature effects were used to predict the effects that +3 and $+5{ }^{\circ} \mathrm{C}$ increases would have on growth and mycotoxin production by Magan et al. (2011). Growth rates and toxin production were determined at maximum rates rather than "typical temperatures" of particular regions. The situation will be different under field conditions, where a range of temperatures and other factors would be experienced such as competing microorganisms. Indeed, Simpson, Thomsett, and Nicholson (2004) revealed that (a) the pathogenicity of different fungi may be additive, and (b) selective advantages may be temperature-dependent.

\section{Predictions concerning precipitation on pre harvest crops}

The IPCC (2007) report states that heavy precipitation is "very likely" in some regions and drought is "likely" in some others. The effects on mycotoxins in crops will be more unpredictable compared to temperature where the effects are more defined (Table 1 ). It is very likely that annual precipitation in European and African Mediterranean regions will decrease greatly as will winter rain in South-Western Australia. At high latitudes precipitation will increase, whilst decreases are likely in most subtropical land (especially at the margins of the subtropics) from intensification of the global hydrological cycle. Extremes of daily precipitation will very likely increase in Northern Europe, Southern and Eastern Asia, Australia, and New Zealand, and in many other regions. Summer drying of mid-continental areas risks the prospect of drought. It is predicted that half of the plant species will be at risk (IPCC, 2007; Miraglia et al., 2009).

Fewer crops are predicted which may reduce the total amounts of mycotoxins from these fewer crops (scenario 2). Consequently, there will be a proportionate reduction in the need to analyse these crops as they will be fewer in quantity. Increased crop stress from heavy precipitation will occur with lower crop yields. These crops will have lowered resistance to fungal invasion and consequently, increases in mycotoxins may occur. Damage to crops, soil erosion, and inability to cultivate land are all predicted in the IPCC (2007) report which will lead to greater fungal ingress and mycotoxin production. Soil erosion allows leaching of nutrients away from the plant and decreasing resistance to fungal infection, which may result in more mycotoxins. Conversely, storage conditions may improve under drought conditions perhaps resulting in fewer mycotoxins from improved drying of crops (Table 1). Drought stress will be important particularly in developing countries. For example, marginal land where stress tolerant sorghum was grown has been replaced with maize especially in Africa (IPCC, 2007; Miraglia et al., 2009) and it is perhaps obvious that, increasingly, mycotoxin methods for analysing maize over sorghum will be required.

\subsection{Aflatoxins}

Maize and peanuts are prone to A. flavus infection during water stress (Table 1) leading to increased preharvest aflatoxin contamination of food. Wallemia sebi, Xeromyces bisporus and certain Chrysosporium spp. are xerotolerant but do not produce mycotoxins per se (Magan et al., 2011), although they are a graphic example of how a group of fungi could supplant another as discussed throughout the current paper. The effect of low/high precipitation phenomena on crops and mycotoxins are provided in Table 1. Late harvesting and heavy rain episodes may influence crop harvest quality and mycotoxin contamination if they are not dried efficiently. On the other hand, the predicted arid and drought climates will assist in drying crops as rain, at or near harvest, implies unacceptable concentrations of aflatoxin in many warm region crops (Cotty \& Jaime-Garcia, 2007).

Arid to semi-arid and drought conditions in tropical countries are associated with contamination and may become widespread in areas normally toxin-free, e.g. when heat associated with drought spreads through the US Midwest. In some regions, infection only occurs when temperatures rise in association with drought (Sanders et al., 1984; Schmitt \& Hurburgh, 1989). Regions where increased heat and drought are indicted (IPCC, 2007) experience greater aflatoxin (Cardwell \& Cotty, 2002), further restricting the area over which crops profitably may be grown.

\subsection{Fusarium toxins and species}

The conditions conducive to contamination of crops in particular with fusaria, deoxynivalenol and fumonisins are provided in Table 1. Long, warm and humid periods encourage cereal ears infection by Fusarium spp. (Jenkinson \& Parry, 1994; Parry, Jenkinson, \& McLeod, 1995), and intense rainfall dispersed fusaria to ears during anthesis. van der Fels-Klerx et al. (2009) developed a European system for emerging mycotoxins (EM) in preharvest wheat supply systems. EM of fusaria were employed as the focus and key indicators were relative humidity, cultivation, temperature, water activity in kernels, rainfall, crop rotation, and fungicide use. Such a system would be invaluable to monitor CC and EM if the gaps in information are overcome. In addition, Miraglia et al. (2009) focus on fusaria in another Europeanbased study of food safety which targets CC which emphasises that mycotoxins need to be evaluated on a case by case basis.

\subsection{Ochratoxin $A$ and grapes}

The effect of environmental conditions can be determined in Table 1 in relation to grape and wine production. Delineating the effect of $a_{\mathrm{w}}$ and temperature on A. carbonarius conidia may aid in understanding the incidence of this ochratoxin A-producing species in vineyard soils and on grapes (Miraglia et al., 2009), although in vivo studies are more important. The effects on the radial growth rate and ochratoxin A production of two Greek A. carbonarius isolates were determined. Both isolates grew optimally at $0.96 a_{\mathrm{w}}$ and from 30 to $35{ }^{\circ} \mathrm{C}$, but maximum ochratoxin A production occurred under 
suboptimal growth conditions ( 0.93 to $0.96 a_{\mathrm{w}}$ and 15 to $20{ }^{\circ} \mathrm{C}$ ). The isolates produced ochratoxin $\mathrm{A}$ at 0.90 to $0.98 \mathrm{a}_{\mathrm{w}}$ and 15 to $30^{\circ} \mathrm{C}$ whereas maximum ochratoxin A production was detected after 25 days of incubation at $0.96 a_{\mathrm{w}}$ and $20{ }^{\circ} \mathrm{C}$. Importantly, the Greek strains were more xerotolerant than others from the Mediterranean basin with important ramifications for CC (Tassou, Natskoulis, Panagou, Spiropoulos, \& Magan, 2007).

Furthermore, the survival of A.carbonarius conidia was determined in an Australian study (Leong et al., 2006) where survival and growth of spores was prolonged at $a_{\mathrm{w}}$ below 0.6 and at low temperatures. Water activities of between 0.6 and $0.9 a_{\mathrm{w}}$ were often more deleterious than 1.0 at above $15{ }^{\circ} \mathrm{C}$. However, at $a_{\mathrm{w}}=1.0$ and $1{ }^{\circ} \mathrm{C}$ conidia lost viability more rapidly than at lower $a_{\mathrm{w}}$. The authors concluded that increased incidence of black Aspergillus spp. in dry soils and from grapes in dry conditions may result partly from prolonged survival of conidia. Fungi associated with grapes and their ability to produce ochratoxin A was investigated (Bellí et al., 2005). However, no significant correlation between black aspergilli presence and other meteorological factors was established. Of course, ochratoxin A may have been affected but was not investigated, also, the use of the term "black" when referring to the fungi does not indicate if the strains could produce ochratoxin.

Table 3 provides data on the lowest moisture content for growth of fungi on various crops and in drought increased $A$. ochraceus and ochratoxin A may be observed. However, Penicillium spp. (e.g. Penicillium verrucosum and $P$. expansum) with their associated mycotoxins, ochratoxin A and patulin respectively, may be threats where floods occur. Unfortunately, the optimum production characteristics for patulin were not provided in Magan et al. (2011) for comparison.

\subsection{General}

The use of "free to air $\mathrm{CO}_{2}$ enrichment" facilities and open top chambers (Ghini, Bettiol, \& Hamada, 2011) and other in vivo studies may be good options for CC research on mycotoxins as studies on isolated fungi, or pre-sterilised grain, do not represent the situation in the field, where even the act of isolating and preserving may alter the fungi (Santos, Paterson, Venâncio, \& Lima, 2010). In addition, the emergence of disease covers evolution of new microbes, expansion in geographic range, increases in incidence, changes in pathways or pathology and infections in new host species or populations (Olival \& Daszak, 2005). Hence it is possible that different mycotoxigenic fungi will evolve and rates of mycotoxin production will change (see Sections 8 and 9).

\section{Post harvest stored grain ecosystems}

The second phase of contamination with mycotoxins may occur from crop maturation until consumption (Tirado, Clarke, et al., 2010; van der Fels-Klerx et al., 2009). The crop could be exposed to warm, moist conditions on the feedlot floor, in the field, during transportation (Tirado, Clarke, et al., 2010) and storage. However, problems begin from heavy rain before harvest and late dry-down (Table 1) with implications regarding CC. These continue during (i) field storage in piles, windrows, and modules, (ii) curing (e.g. in nut crops under tarpaulin) and (iii) use by consumers. The key environmental factors of temperature, water availability and gas composition influence production. Spoilage will not happen if grain is stored at $\leq 0.70 a_{\mathrm{w}}$ and CC which facilitates obtaining this level will assist and vice versa. For example, the drying of chilies in Pakistan uses particularly low technology where the fruit can be left to dry on the plant, or dried on the ground (Iqbal et al., 2011) and which will be affected by CC. There are various interactions between factors which assist safe storage (Wallace \& Sinha, 1981). In addition, farms which can afford to keep silos within safe ranges may "only" experience increased costs from more energy expenditure (Paterson \& Lima, 2010a). Storage will be difficult in cases where CC results in high moisture levels leading to problems with drying crops (Table 1).

Interspecific and intraspecific interactions will occur depending on the prevailing environmental conditions. Magan et al. (2003) developed an Index of Dominance $(I)$ to interpret dominance in grains which varied with $a_{\mathrm{w}}$ and temperature. Presumably, an assessment of the role of mycotoxins was outside the remit of the study. The most competitive species in wheat grain in the UK were Aspergillus fumigatus, Aspergillus nidulans, Penicillium brevicompactum, Penicillium hordei, and Penicillium roqueforti, none of which are the predominant mycotoxigenic species (with the possible exception of $P$. roqueforti). Furthermore, an ochratoxin A-producing strain of $A$. ochraceus dominated A. candidus and A. flavus at $18{ }^{\circ} \mathrm{C}$ in situ: At $30^{\circ} \mathrm{C}$ it was not dominant against $A$. flavus (Magan et al., 2003), indicating that in temperate climates $A$. flavus may become problematic, if the temperature increases to $30^{\circ} \mathrm{C} . \mathrm{F}$. verticillioides and Fusarium proliferatum form niches with other storage fungi such as Penicillium spp., A. flavus and A. ochraceus at 25 and $30^{\circ} \mathrm{C}$. A. ochraceus, and Alternaria alternata demonstrated changed interactions with altered environment. The niche overlap is in a state of flux and influenced significantly by water availability, temperature and nutrient status. The importance of such fluxes is crucial to understanding and controlling mycotoxigenic fungi in the stored grain ecosystem, as will occur during CC, although more information on how mycotoxins affect competition is required (Paterson \& Lima, 2010a).

Fusarium species incubated with Aspergillus niger resulted in an increase in fumonisin especially at $0.98 a_{\mathrm{w}}$, although under drier conditions an increase did not occur on maize (Marín, Sanchis, Rull, Ramos, \& Magan, 1998), relevant to regions that will become dryer from CC. However, A. niger can also produce fumonisin (Frisvad, Smedsgaard, Samson, Larsen, \& Thrane, 2007; Noonim, Mahakarnchanakul, Nielsen, Frisvad, \& Samson, 2009) and so the increase may relate to both fungi producing these compounds which was not considered. Deoxynivalenol was stimulated from F. culmorum with Microdochium nivale on wheat grain with $0.995 a_{\mathrm{w}}$, and reduced under drier conditions $\left(0.955 a_{\mathrm{w}}\right)$ with Alternaria tenuissima, Cladosporium herbarum and Penicillium verrucosum. Research on the effect of mycotoxins on the other fungi requires being undertaken.

\section{Carbon dioxide change and mycotoxin production}

Slightly elevated $\mathrm{CO}_{2}$ concentrations and interactions with temperature and water availability may stimulate growth of some mycotoxigenic species, especially under water stress (Magan et al., 2011), although the information relating to this is slight. The concentration would increase from $0.03 \%$ to $0.08 \%$ in the atmosphere if the predicted $\mathrm{CO}_{2}$ increase from $\mathrm{CC}$ is maintained for the next 100 years (IPCC, 2007). Unfortunately, there is currently a lack of information on the effect of these low concentrations on fungi and mycotoxin production, hence more work is required. Magan et al. (2011) reported the effect of high concentrations on growth which may not be relevant to the low levels from CC. However, the increase in $\mathrm{CO}_{2}$ is predicted to increase the metabolism of crops providing higher yields. Increased stomata closure will be associated inevitably with lower latent heat loss, thereby increasing leaf temperatures and affecting how and which fungi infect the plant (DaMatta, Grandis, Arenque, \& Buckeridge, 2010; Paterson \& Lima, 2010a). It is now appropriate to consider the effects of $\mathrm{CC}$ on a region to region basis.

\section{Specific regions}

The temperature rise is expected to be highest over land and at high latitudes in the Northern hemisphere during the winter period (IPCC, 2007) and lowest at the coast, whilst increasing going inwards. Warming is lower in moist than arid regions in geographically similar areas and less warming over the Southern oceans and North Atlantic is expected (IPCC, 2007). A decrease in frost days and an increase in 
growing season length are projected to occur almost everywhere in the mid and high latitudes.

\subsection{Africa 2020}

Crop yields will be reduced by $50 \%$ in Africa (IPCC, 2007). With such a reduction in crops the overall total mycotoxins may be expected to decrease (scenario 2), although data to confirm this is required. However, an increase of 5 to $8 \%$ of arid and semi-arid land is also predicted which will cause drought stress on crops and perhaps more mycotoxins (Table 1). Furthermore, these conditions in tropical countries are associated with contamination (Paterson \& Lima, 2010a; Table 1): changes in climate may lead to acute aflatoxicosis (Lewis et al., 2005; Paterson \& Lima, 2010f). An increase in crops may be expected to occur in some currently cooler areas (e.g. regions at higher altitudes) (IPCC, 2007). Worsening food security and exacerbated malnutrition will occur with mycotoxins contributing to more disease in already weakened people and animals. However, storage conditions may improve (Miraglia et al., 2009). For example, chilies in Pakistan are often dried on the ground and this would be facilitated at higher temperatures (Iqbal et al., 2011).

\subsection{Europe}

A magnification of regional differences in natural resources and assets in Europe is predicted (IPCC, 2007). High temperature and drought will reduce water availability and crop productivity in the south. Warming in the order of $3{ }^{\circ} \mathrm{C}$ will result in a poleward dispersal of many plant species, or even entire communities, and changes in species assemblages (Pritchard, 2011). Vines are an example (Paterson \& Lima, 2010a), with the possibility of increased ochratoxin A in UK wines (Paterson \& Kozakiewicz, 2001) becoming a reality. There may be increased aflatoxin, ochratoxin A from Aspergillus spp., and fumonisins in sub Mediterranean counties (e.g., North Portugal) as the temperature increases. For example, aflatoxins in Northern Italy are now being reported (Giorni et al., 2008), as is the isolation of $A$. flavus from Hungary (Varga et al., 2007).

In some areas the quality of soils will deteriorate and in others, landslides and erosion phenomena due to run off will occur (Miraglia et al., 2009). Increased temperature and altered precipitation patterns might result in increased losses of soil minerals by leaching and erosion. Southern Europe will probably experience decreases of spring-sown crops (e.g. maize, sunflowers, and soybean) with them becoming more suitable for cultivation in Northern areas. Maize production is expected to increase by $30-50 \%$ in Northern European regions but to decrease strongly in the south of Europe. The mycotoxin problem may "follow the crop".

In Southern and South-Eastern Europe (i.e. Portugal, Spain, Southern France, Italy, Slovenia, Greece, Malta, Cyprus, Bulgaria, and Southern Romania) an increase in the order of $4-5{ }^{\circ} \mathrm{C}$ is projected and water availability will be reduced particularly in summer. This effect combined could induce (i) decreased agricultural yields (in the range of $10-30 \%$ in many regions), (ii) drought, (iii) heat waves, (iv) soil and ecosystem degradation, and ( $v$ ) desertification. The increase of violent rainfall will augment erosion and loss of organic matter from soil (European Commission, 2007). The effects on mycotoxins in crops can be assessed from Table 1 , where drought and heat may increase aflatoxin levels generally.

Western and Atlantic Europe countries (e.g. Benelux, Western and Northern France, Northern Germany, United Kingdom (UK), Irish Republic, the Netherlands, and Denmark) will experience an increase of ca. $2.5-3.5^{\circ} \mathrm{C}\left(2-3{ }^{\circ} \mathrm{C}\right.$ for UK and Irish Republic) with dryer and hotter summers. Due to higher volumes and intensities of precipitation, strong storms and floods are projected to be more frequent particularly in winter (European Commission, 2007). Proper drying down of crops may be impaired causing increased mycotoxins in stored products
(Table 1). CC will decrease UK spring rainfall and increase summer and winter temperatures over the next 50 years (Hulme et al., 2002; Miraglia et al., 2009). Impacts over the 21 st century in the UK can be summarised as milder/wetter winters, hotter/drier summers and more extreme weather incidents. CC may indeed lead to different crops being grown from those normally associated with UK, again bring with them associated mycotoxins, assuming that the "Parasites Lost" phenomenon does not arise (see Section 7).

Areas of central Europe include Poland, Czech Republic, Slovakia, Hungary, Northern Romania, Southern and Eastern Germany, and Eastern Austria. An increase in the order of $3-4{ }^{\circ} \mathrm{C}\left(4-4.5^{\circ} \mathrm{C}\right.$ for Central Europe and Black Sea Regions) is projected and precipitation may increase in winter and decrease in summer, with an increased risk of floods. Agriculture is expected to be affected by soil erosion, loss of soil organic matter, migration of pests and diseases, summer drought and high temperature. However, in some regions, longer growing seasons will benefit crops (European Commission, 2007). It is relevant to point out that aflatoxin-producing fungi are being discovered from Hungary where before they were not (Varga et al., 2007).

In Norway, Sweden, Finland, and Baltic States (i.e. northern Europe) temperature increase in the order of $3-4.5^{\circ} \mathrm{C}$ and an increase of yearly precipitation up to $40 \%$ are projected with risks for floods: Winter will be wetter (European Commission, 2007). The overall results of CC would be an increase in crop yield (10-30\% for warming in the range $1-3{ }^{\circ} \mathrm{C}$ ) and novel crops may be cultivated. Crop production could benefit due to a "lengthened growing seasons and longer frost free periods". Crop yields and the area arable with crops are expected to expand in the region. From an a priori perspective, this will tend to increase the total amount of mycotoxins (scenario 1), although more work to confirm this association is required.

\subsection{Australia/New Zealand 2030}

Australia and New Zealand present challenges peculiar to these countries. One issue is that more pasture-based grasses are grown as food for horses, cattle and sheep (Cawdell-Smith, Scrivener, \& Bryden, 2010) with "sheep staggers" being an issue of possible increased occurrence. Conventional crops are also produced on a large scale. Australia will face increasing water security problems and production from agriculture will decline due to drought. However, there are initial increased yields projected for New Zealand. Australia may become too hot and dry for many crops per se, although problems may be mitigated by this being a developed region in that Good Agricultural Practice (GAP), mycotoxin analyses, fungal identifications, etc. are all feasible at a high standard.

Important crops include vegetables, wheat and other cereals, sugarcane, deciduous fruits and grapes many of which are susceptible to mycotoxin contamination. Australian temperatures will rise dramatically by 2100 (Chakraborty et al., 1998). Changes (a) in host-pathogen interactions and geographical distribution will occur resulting in crop losses and (b) will occur in the importance, type and amount of pathogens and diseases. High $\mathrm{CO}_{2}$ and UV-B radiation may accelerate pathogen evolution and hence overcome host resistance from increased fecundity.

\subsection{Asia}

Mycotoxin risk is more difficult to ascertain for Asia from the IPCC report as there is a lack of information. The situation may be somewhat similar to Latin America, in that change will occur in already hot regions in some cases, with rain forest implications, and in countries which could be considered as developing. Predictions relating to tropical countries are also relevant. However, fresh water availability is to decrease by 2050 and coastal areas are at greatest risk from more flooding from the sea and rivers. Fewer crops/yields will occur from CC in currently warm regions and the crops produced will 
be of lower quality due to the stress effects of CC. Consequently, they may contain more mycotoxins per unit weight of crops. Novel hot and dry conditions may affect storage conditions in positive manners. There will be greater damage from flooding, more ingress of fungi via the damaged crop, and consequently increased mycotoxins. Mycotoxins could impair seriously the availability of food and feed in developing countries in particular (Miraglia et al., 2009). In currently hot climates (IPCC, 2007) the temperatures reached will be extremely high and may lead to the extinction of the fungi. The temperatures in Pakistan have reached a staggering $53.7^{\circ} \mathrm{C}$ (Iqbal et al., 2011) as reported in this study of aflatoxin in chilies, which will tend to decrease the levels of fungi generally. These temperatures are not considered in the isopleths of Sanchis and Magan (2004) and are much higher than the optima and higher than the parameters employed in Garcia et al. (2011). Indeed, the temperatures are of the order that could lead to extinction of fungal species (see Pringle et al., 2011).

\subsection{Latin America 2050}

There will be a significant increase in temperature, and decreased soil water (IPCC, 2007). The tropical forest will become savanna grassland and semi arid land crops will be replaced by arid vegetation.
Significantly, tropical species extinction will occur. Crop productivity will decrease and lead to adverse food security situations (IPCC, 2007). It is stated that increased soybean production will occur in temperate zones, therefore, soybean mycotoxins may increase from there being more total crop. Soybeans have associated with them numerous mycotoxin producing fungi (CAST, 2003) and the potential contamination by mycotoxins exists. However, the crop is resistant to A. flavus growth and aflatoxin production especially if the crop is kept under dry conditions. Pildain et al. (2008) mention that Aspergillus arachidicola and Aspergillus minisclerotigenes were described as novel species from Argentinean peanuts and the fungi produced aflatoxin in culture. These isolates grew well at $42{ }^{\circ} \mathrm{C}$ and it is possible that these species may be replacing $A$. flavus.

\subsection{North America}

Warming in the western mountains of the USA will cause decreased snowpack, more winter flooding and reduced summer river flows (IPCC, 2007): water resources will be stretched. However, pre 2050 there will be an increase in rain-fed agriculture from 5 to $20 \%$ although with important variability amongst regions. Crops will be challenged at the warm end of the range and there will be a lack of water resources as mentioned. It is relevant that Bt cottonseed

a

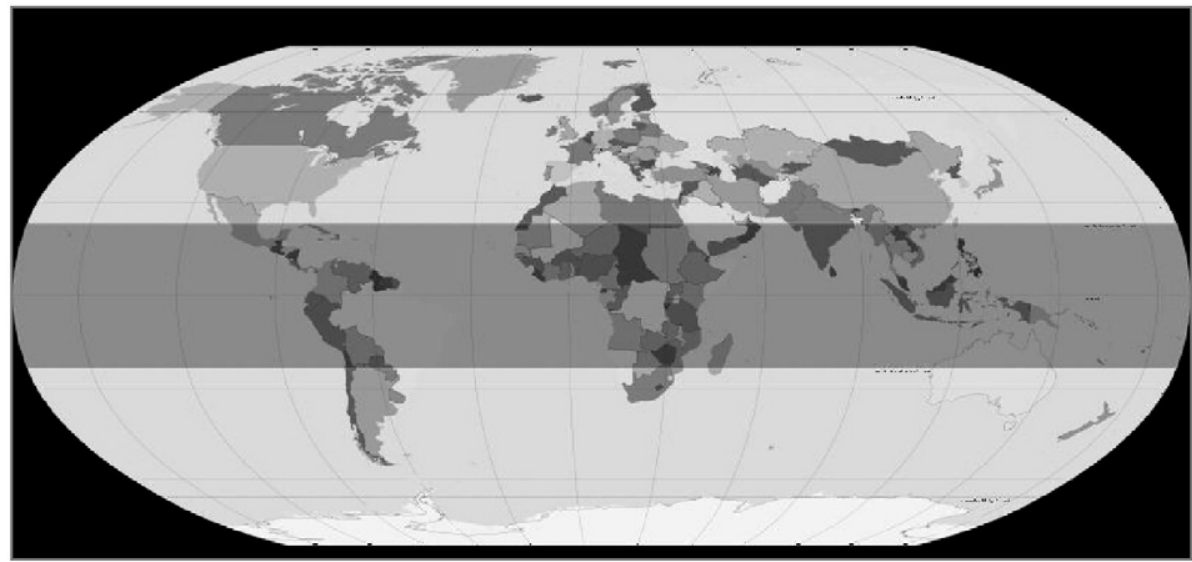

b

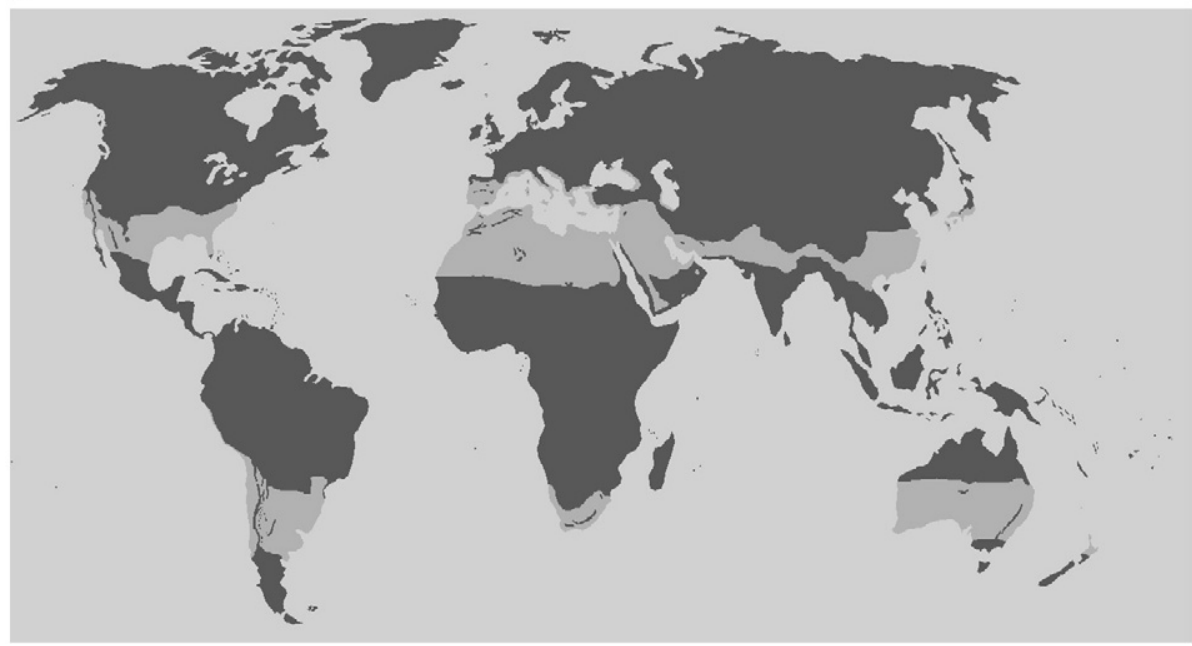

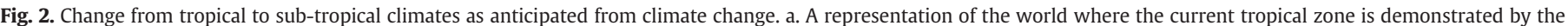

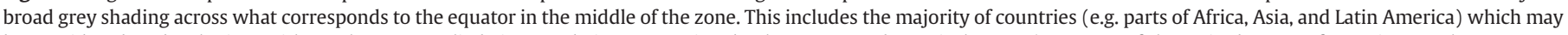

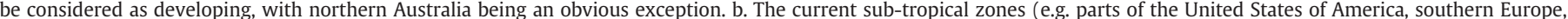

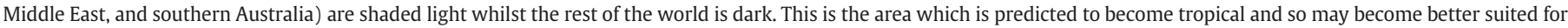

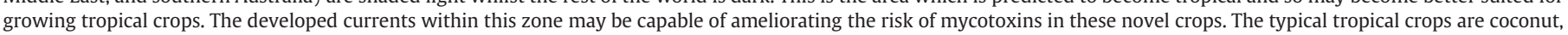
coffee, cocoa, soybean and maize. 
produced in Arizona had $5000 \mathrm{ppb}$ of aflatoxin which resulted from unusually warm and humid conditions (Table 1 ). The predicted floods and drought will lead to more mycotoxins for reasons discussed above. Cool areas will change to hot, leading to more mycotoxins and more "hot temperature mycotoxins". The floods and higher temperature will result in more difficult storage problems as these will favour fungal growth and mycotoxin production.

As part of the general "movement of crops to the Poles" (Pritchard, 2011) the production of tropical crops such as coconut, maize, soybeans, coffee, and cocoa may become optimal in currently sub tropical regions such as the Southern United States of America. In contrast, the current sub-tropical countries consist of the major developed countries, e.g. parts of the USA (Fig. 2). If we assume that tropical weather becomes the norm in currently sub tropical regions then the developed countries may be able to cope better with increased mycotoxins in tropical crops.

\section{Parasites lost}

The "Parasites lost" phenomenon may occur as crops are moved to new growing regions. Such crops often thrive, with increases in body mass and spread, from the loss of their associated pests resulting in a potential advantage in terms of fungi and mycotoxins. The introduced plant may experience the "enemy release" phenomenon which has been hypothesised, resulting in reduced natural enemy attack. For example, 473 plant species naturalised to the United States from Europe had on average, $84 \%$ fewer fungi infecting each plant species. The results indicated that the impact of invasive plants may be a function of release from and (in a few cases) accumulation of, natural enemies, including pathogens (Mitchell \& Power, 2003).

\section{Toxigenic fungi, biosynthesis rates and climate models}

It can be predicted that CC will alter rates of mycotoxin formation (cf. Singh, Bardgett, Smith, \& Reay, 2010). Global changes and the rate of mycotoxin formation can change according to the response of fungal communities (Fig. 3). However, the consequences are not known if CCs beyond the limits. For example, if the structure of the fungal community changes in such a way that the function also alters, a discontinuity in the response may occur and the response could move to a different path (Fig. 3, part c). Understanding these potential threshold effects remain key challenges in CC and mycotoxicology.

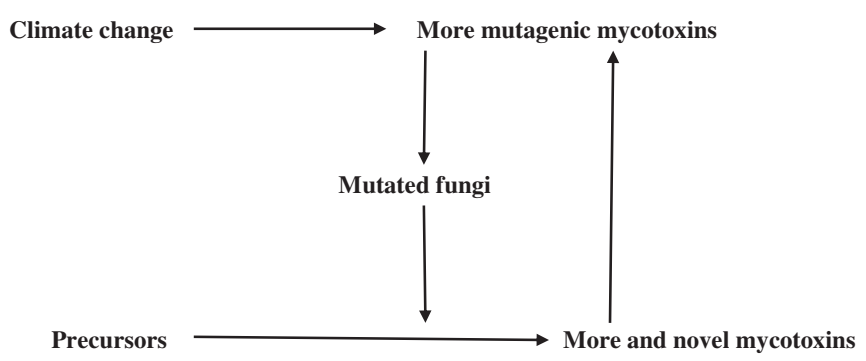

Rate $=\mathbf{k}$

Fig. 4. The climate change mycotoxin cycle: Climate change will result in increased mycotoxins in crops many of which are mutagenic. This may lead to mutated fungi which will change the rate of mycotoxin production to new limits and to different mycotoxins. Some of these will be mutagenic which again create a mutagenic pressure on existing fungi in a cyclical manner in this scheme (see also Fig. 3).

\section{The climate change mycotoxin cycle}

This novel concept considers how CC could activate the "furnace of evolutionary change" (Fig. 4). Paterson, Sariah, Lima, Zainal Abidin, and Santos (2008) and Paterson and Lima (2009) discussed how mutagens produced during the culturing of fungi may exert changes in the structure to the DNA (e.g. mutations) affecting diagnostic methods and phylogenetic schemes. The possibility of increased mutation in fungi from CC is mentioned in Paterson and Lima (2010a) and the emergence of disease include evolution of new microbes (Olival \& Daszak, 2005). Many mycotoxins are mutagenic and are well-known as a source of mutation in the environment. CC may result in increased amounts and different types of mutagenic mycotoxins on crops, which could lead to mutated strains of fungi also capable of producing mutagenic mycotoxins and so on in a cyclical manner (Fig. 4). The increase in UV radiation from CC related temperature increase will also increase mutations.

\section{Amelioration strategy}

Speijers et al. (2010) mention that GAP and Good Manufacturing Practice are useful to implement for the control of mycotoxins. Preventative and corrective measures are GAP, plant breeding and detoxification. Hazard Analysis and Critical Control Point schemes for

a

b Community unchanged

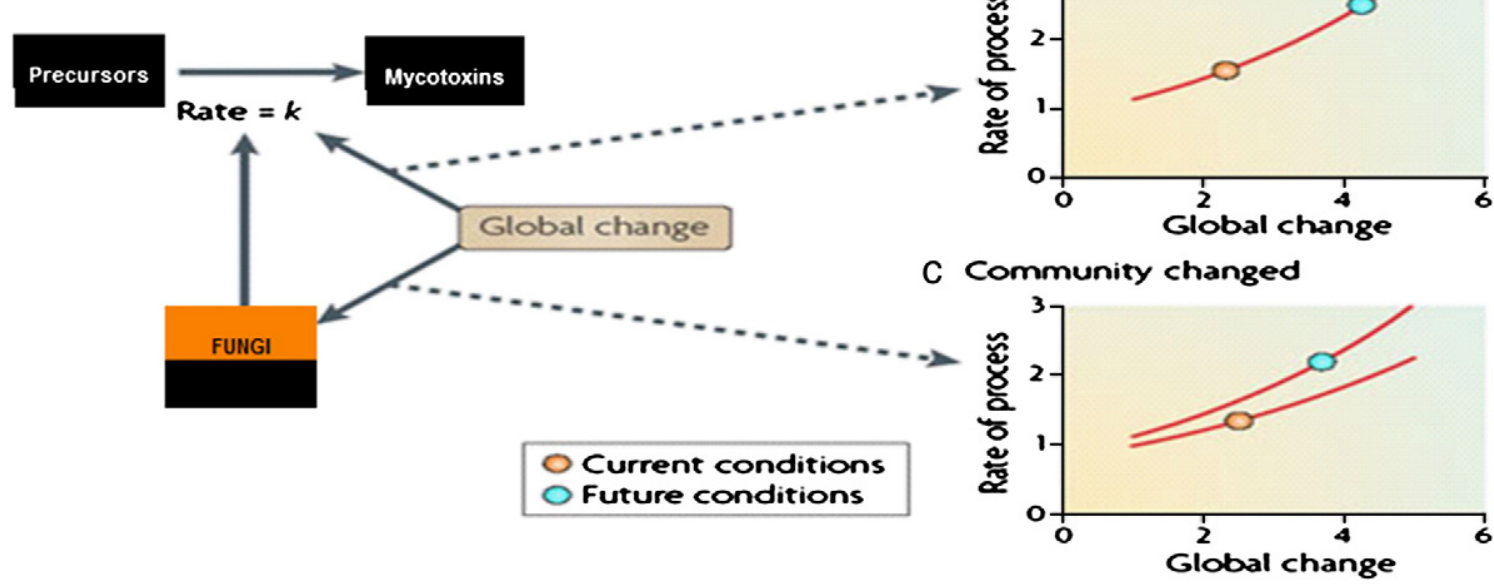

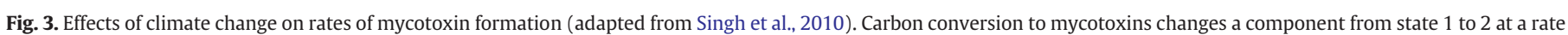

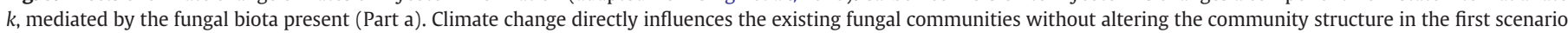

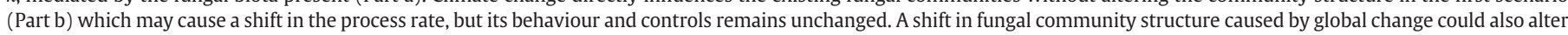
the fundamental control mechanism of the process as in the second scenario (Part c). 
mycotoxin control need to be further introduced. Crops can be planted during cooler parts of the season to avoid heat stress and Iqbal et al. (2011) demonstrated lower aflatoxins levels in chillies planted in winter in Pakistan. The introduction of GM crops could be considered. Training and capacity building with respect to mycotoxins per se, need to be improved, especially for developing countries. It is recommended that in regions where more crops will be grown from CC, mycotoxin analyses are maintained at a sufficiently high level and where fewer crops are grown adequate levels of analyses remain. Changing of cropping patterns, aflatoxin management technologies, and detoxification can all be considered (Magan et al., 2003) to avoid future exposure. van der Fels-Klerx et al. (2009) developed a European system for EM of fusaria in wheat. The indicators were, inter alia, relative humidity, temperature, water activity in kernels and rainfall. Such a system would be invaluable to monitor CC and EM if the gaps in information are overcome. Finally, the underlying policy frameworks in approaching these problems have to be considered.

\section{Conclusions}

In general there will be more mycotoxins in the new CC era. There may be an increase of "high temperature fungi and mycotoxins" such as A. flavus and aflatoxin. An "up shift" in regions will be experienced, e.g. sub-tropical regions become tropical, with associated changes in mycotoxin contamination patterns. There is little or no consideration of mycotoxins such as patulin, T-2 toxin, nivalenone, zearalenone, ergot alkaloids and many of the "second tier mycotoxins", in terms of CC: Many of these have confirmed toxicities (Paterson \& Lima, 2010f) and amelioration strategies for only a few mycotoxins may be detrimental to others. Finally, more data are required on how mycotoxins per se affect competitors within the food/crop systems.

Priorities in research are described in Magan et al. (2011). They include (a) harmonisation of procedures for monitoring mycotoxins, (b) evaluating reliable databases on the geographical distribution of mycotoxins, (c) development of models, and (d) evaluation of the influence of environmental factors on these compounds. To this we add establishing research plots in different climatic zones where identical crops are grown with a view to measuring the effects on mycotoxins, hence providing valid in vivo data. Finally, efforts must be strengthened to ensure greenhouse gas emissions are controlled effectively to enable CC to be decreased.

\section{References}

Amici, A. M., Minghetti, A., Scotti, T., Spalla, C., \& Tognoli, L. (1969). Production of peptide ergot alkaloids in submerged culture by three isolates of Claviceps purpurea. Applied Microbiology, 18(3), 464-468.

Baert, K., Devlieghere, F., Flyps, H., Oosterlinck, M., Ahmed, M. M., Rajković, A., et al. (2007). Influence of storage conditions of apples on growth and patulin production by Penicillium expansum. International Journal of Food Microbiology, 119(3), $170-181$.

Battilani, P., Giorni, P., Bertuzzi, T., Formenti, S., \& Pietri, A. (2006). Black aspergilli and ochratoxin A in grapes in Italy. International Journal of Food Microbiology, 111, S53-S60.

Bellí, N., Marín, S., Coronas, I., Sanchis, V., \& Ramos, A. J. (2007). Skin damage, high temperature and relative humidity as detrimental factors for Aspergillus carbonarius infection and ochratoxin A production in grapes. Food Control, 18(11), 1343-1349.

Bellí, N., Mitchell, D., Marín, S., Alegre, I., Ramos, A. J., Magan, N., et al. (2005). Ochratoxin A-producing fungi in Spanish wine grapes and their relationship with meteorological conditions. European Journal of Plant Pathology, 113(3), 233-239.

Beniston, M., \& Diaz, H. F. (2004). The 2003 heat wave as an example of summers in a greenhouse climate? Observations and climate model simulations for Basel, Switzerland. Global and Planetary Change, 44(1-4), 73-81.

Bock, C. H., Mackey, B., \& Cotty, P. J. (2004). Population dynamics of Aspergillus flavus in the air of an intensively cultivated region of south-west Arizona. Plant Pathology, 53(4), 422-433.

Boyd, M. L., \& Cotty, P. J. (2001). Aspergillus flavus and aflatoxin contamination of leguminous trees of the Sonoran Desert in Arizona. Phytopathology, 91(9), 913-919.

Cardwell, K. F., \& Cotty, P. J. (2002). Distribution of Aspergillus section flavi among field soils from the four agroecological zones of the republic of Bénin, West Africa. Plant Disease, 86(4), 434-439.
CAST (2003). Mycotoxins: Risks in plant, animal, and human systems. Ames IA: Council for Agricultural Science and Technology.

Cawdell-Smith, A. J., Scrivener, C. J., \& Bryden, W. L. (2010). Staggers in horses grazing paspalum infected with Claviceps paspali. Australian Veterinary Journal, 88(10), 393-395.

Chakraborty, S., Murray, G. M., Magarey, P. A., Yonow, T., O'Brien, R. G., Croft, B. J., et al. (1998). Potential impact of climate change on plant diseases of economic significance to Australia. Australasian Plant Pathology, 27(1), 15-35.

Clouvel, P., Bonvarlet, L., Martinez, A., Lagouarde, P., Dieng, I., \& Martin, P. (2008). Wine contamination by ochratoxin $\mathrm{A}$ in relation to vine environment. International Journal of Food Microbiology, 123(1-2), 74-80.

Cole, R. J., Sanders, T. H., Dorner, J. W., \& Blankenship, P. D. (1989). Environmental conditions required to induce preharvest aflatoxin contamination of groundnut: Summary of six years research. In D. McDonald, \& V. K. Mehan (Eds.), Aflatoxin contamination of groundnut, India: Proceedings of international workshop (pp. 279-287). : ICRISAT.

Cotty, P. J., \& Jaime-Garcia, R. (2007). Influences of climate on aflatoxin producing fungi and aflatoxin contamination. International Journal of Food Microbiology, 119(1-2), 109-115.

Crutzen, P. J., \& Stoermer, E. F. (2000). The “Anthropocene”. International GeosphereBiosphere Programme Newsletter, No., 41, 17-18.

DaMatta, F. M., Grandis, A., Arenque, B. C., \& Buckeridge, M. S. (2010). Impacts of climate changes on crop physiology and food quality. Food Research International, 43(7), 1814-1823.

de la Campa, R., Hooker, D. C., Miller, J. D., Schaafsma, A. W., \& Hammond, B. G. (2005). Modelling effects of environment, insect damage, and Bt genotypes on fumonisin accumulation in maize in Argentina and the Philippines. Mycopathologia, 159(4), 539-552.

European Commission (2007). Adapting to climate change in Europe - Options for EU action. Green paper from the Commission to the Council, the European Parliament, the European Economic and Social Committee and the Committee of the Regions, COM (2007)354 final, SEC (2007), 849. Brussels: European Commission.

Freire, F., Kozakiewicz, Z., \& Paterson, R. (2000). Mycoflora and mycotoxins in brazilian black pepper, white pepper and brazil nuts. Mycopathologia, 149(1), 13-19.

Frisvad, J. C., Smedsgaard, J., Samson, R. A., Larsen, T. O., \& Thrane, U. (2007). Fumonisin B2 production by Aspergillus niger. Journal of Agricultural and Food Chemistry, 55(23), 9727-9732.

Garcia, D., Ramos, A. J., Sanchis, V., \& Marín, S. (2011). Modelling the effect of temperature and water activity in the growth boundaries of Aspergillus ochraceus and Aspergillus parasiticus. Food Microbiology, 28(3), 406-417.

Ghini, R., Bettiol, W., \& Hamada, E. (2011). Diseases in tropical and plantation crops as affected by climate changes: Current knowledge and perspectives. Plant Pathology, 60(1), 122-132.

Giorni, P., Battilani, P., \& Magan, N. (2008). Effect of solute and matric potential on in vitro growth and sporulation of strains from a new population of Aspergillus flavus isolated in Italy. Fungal Ecology, 1(2-3), 102-106.

Hooker, D. C., Schaafsma, A. W., \& Tamburic-Ilincic, L. (2002). Using weather variables pre- and post-heading to predict deoxynivalenol content in winter wheat. Plant Disease, 86(6), 611-619.

Hulme, M., Jenkins, G. J., Lu, X., Turnpenny, J. R., Mitchell, T. D., Jones, R. G., et al. (2002). Climate change scenarios for the United Kingdom. 120 pp.,Available from. The UKCIP02 scientific report, Tyndall centre for climate change research. Norwich, UK: School of Environmental Sciences, University of East Anglia www.ukcip.org.uk Accessed 16 Mar 2011.

IPCC (2007). Intergovernmental panel on climate change report. 52 pp.. Climate Change 2007: Synthesis Report.

Iqbal, S. Z., Paterson, R. R. M., Bhatti, I. A., \& Asi, M. R. (2011). Comparing aflatoxin contamination in chilies from Punjab, Pakistan produced in summer and winter. Mycotoxin Research, 27(2), 75-80.

Isebaert, S., De Saeger, S., Devreese, R., Verhoeven, R., Maene, P., Heremans, B., et al. (2009). Mycotoxin-producing Fusarium species occurring in winter wheat in Belgium (Flanders) during 2002-2005. Journal of Phytopathology, 157(2), 108-116.

Jaime-Garcia, R., \& Cotty, P. J. (2003). Aflatoxin contamination of commercial cottonseed in south Texas. Phytopathology, 93(9), 1190-1200.

Jeger, M. J., \& Pautasso, M. (2008). Plant disease and global change - The importance of long-term data sets. The New Phytologist, 177(1), 8-11.

Jenkinson, P., \& Parry, D. W. (1994). Splash dispersal of conidia of Fusarium culmorum and Fusarium avenaceum. Mycological Research, 98(5), 506-510.

Jennings, P., Coates, M. E., Walsh, K., Turner, J. A., \& Nicholson, P. (2004). Determination of deoxynivalenol- and nivalenol-producing chemotypes of Fusarium graminearum isolated from wheat crops in England and Wales. Plant Pathology, 53(5), 643-652.

Johnston, W. J., Golob, C. T., Sitton, J. W., \& Schultz, T. R. (1996). Effect of temperature and postharvest field burning of Kentucky bluegrass on germination of sclerotia of Claviceps purpurea. Plant Disease, 80(7), 766-768.

Leong, S. L., Hocking, A. D., \& Scott, E. S. (2006). Effects of water activity and temperature on the survival of Aspergillus carbonarius spores in vitro. Letters in Applied Microbiology, 42(4), 326-330.

Lewis, L., Onsongo, M., Njapau, H., Schurz-Rogers, H., Luber, G., Kieszak, S., et al. (2005). Aflatoxin contamination of commercial maize products during an outbreak of acute aflatoxicosis in eastern and central Kenya. Environmental Health Perspectives, 113(12), 1763-1767.

Magan, N., Hope, R., Cairns, V., \& Aldred, D. (2003). Post-harvest fungal ecology: Impact of fungal growth and mycotoxin accumulation in stored grain. European Journal of Plant Pathology, 109(7), 723-730.

Magan, N., Medina, A., \& Aldred, D. (2011). Possible climate-change effects on mycotoxin contamination of food crops pre- and postharvest. Plant Pathology, 60(1), 150-163. 
Marín, S., Sanchis, V., Rull, F., Ramos, A. J., \& Magan, N. (1998). Colonization of maize grain by Fusarium moniliforme and Fusarium proliferatum in the presence of competing fungi and their impact on fumonisin production. Journal of Food Protection, 61(11), 1489-1496.

Miraglia, M., de Santis, B., \& Brera, C. (2008). Climate change: Implications for mycotoxin contamination of foods. Journal of Biotechnology, 136S, S711-S716.

Miraglia, M., Marvin, H. J. P., Kleter, G. A., Battilani, P., Brera, C., Coni, E., et al. (2009). Climate change and food safety: An emerging issue with special focus on Europe. Food and Chemical Toxicology, 47(5), 1009-1021.

Mitchell, C. E., \& Power, A. O. (2003). Release of invasive plants from fungal and viral pathogens. Nature, 421(6923), 625-627.

Montes-Belmont, R., Méndez-Ramírez, I., \& Flores-Moctezuma, E. (2002). Relationship between sorghum ergot, sowing dates, and climatic variables in Morelos, Mexico. Crop Protection, 21(10), 899-905.

Munkvold, G. P., \& Desjardins, A. E. (1997). Fumonisins in maize can we reduce their occurrence? Plant Disease, 81(JUN), 556-565.

Noonim, P., Mahakarnchanakul, W., Nielsen, K. F., Frisvad, J. C., \& Samson, R. A. (2009). Fumonisin B2 production by Aspergillus niger in Thai coffee beans. Food Additives $\mathcal{E}$ Contaminants. Part A, Chemistry, Analysis, Control, Exposure E Risk Assessment, 26(1), 94-100.

Olival, K. J., \& Daszak, P. (2005). The ecology of emerging neurotrophic viruses. Journal of Neurovirology, 11(5), 441-446.

Parry, D. W., Jenkinson, P., \& McLeod, L. (1995). Fusarium ear blight (scab) in small grain cereals - A review. Plant Pathology, 44(2), 207-238.

Paterson, R. R. M., (in press). Climate change paper does discuss the issues. Plant Pathology.

Paterson, R., \& Kozakiewicz, Z. (2001). Ochratoxin A in grapes and wine - A challenge for UK vineyards? (125th Edition). : The Grape Press.

Paterson, R. R. M., \& Lima, N. (2009). Mutagens manufactured in fungal culture may affect DNA/RNA of producing fungi. Journal of Applied Microbiology, 106(4), 1070-1080.

Paterson, R. R. M., \& Lima, N. (2010a). How will climate change affect mycotoxins in food? Food Research International, 43(7), 1902-1914.

Paterson, R. R. M., \& Lima, N. (2010b). The weaponisation of mycotoxins. In A. Varma, \& M. K. Rai (Eds.), Mycotoxins in food, feed and bioweapons (pp. 367-384). Berlin, Germany: Springer Verlag.

Paterson, R. R. M., \& Lima, N. (2010c). World climate change and mycotoxins in food and water. World Mycotoxin Forum. Abstract and Presentation, World Mycotoxin Forum. November 8-10, 2010. Noordwijkerhout, the Netherlands (pp. 69-70).

Paterson, R. R. M., \& Lima, N. (2010d). World climate change and mycotoxins in relation to food safety. 1st International Conference on Food Safety and Security under Changing Climate. Parkroyal Hotel December 6-7, 2010, Penang - Malaysia. Presentation, abstract, and $C D$. Presentaion slides available at: http://www.selamat.wur.nl/UK/Training + and +workshops/2010+Malaysia/(20/1/11).

Paterson, R. R. M. \& Lima, N. (2010e). World climate change presents a serious threat to food and drink from mycotoxigenic fungi. Presentation abstract. International Mycotoxin Conference, MycoRed 2010, Global Mycotoxin Reduction Strategies: Asia and Pacific Rim, Penang, Malaysia 1-4 December 2010.

Paterson, R. R. M., \& Lima, N. (2010f). Toxicology of mycotoxins. In A. Luch (Ed.), Molecular, clinical and environmental toxicology, Volume 2 Clinical Toxicology. EXP, 100. (pp. 31-63) Germany: Springer.

Paterson, R. R. M., Sariah, M., Lima, N., Zainal Abidin, M. A., \& Santos, C. (2008). Mutagenic and inhibitory compounds produced by fungi affect detrimentally their PCR-based diagnosis and phylogenetic analyses. Current Bioactive Compounds, 4(4), 245-257.

Paul, P. A., Lipps, P. E., \& Madden, L. V. (2006). Meta-analysis of regression coefficients for the relationship between Fusarium head blight and deoxynivalenol content of wheat. Phytopathology, 96(9), 951-961.

Pildain, M. B., Frisvad, J. C., Vaamonde, G., Cabral, D., Varga, J., \& Samson, R. A. (2008). Two novel aflatoxin-producing Aspergillus species from Argentinean peanuts. International Journal of Systematic and Evolutionary Microbiology, 58(3), 725-735.

Pringle, A., Barron, E., Sartor, K., \& Wares, J. (2011). Fungi and the anthropocene: Biodiversity discovery in an epoch of loss. Fungal Ecology, 4(2), 121-123.

Pritchard, S. G. (2011). Soil organisms and global climate change. Plant Pathology, 60(1), 82-99.

Řeháček, Z. (1991). Physiological controls and regulation of ergot alkaloid formation. Folia Microbiologica, 36(4), 323-342.

Rosenzweig, C., Iglesias, A., Yang, X. B., Epstein, P. R., \& Chivian, E. (2001). Climate change and extreme weather events; implications for food production, plant diseases, and pests. Global Change and Human Health, 2(2), 90-104.

Sanchis, V., \& Magan, N. (2004). Environmental conditions affecting mycotoxins. In N. Magan, \& M. Olsen (Eds.), Mycotoxins in food: Detection and control (pp. 174-189). Boca Raton, FL: CRC Press.
Sanders, T. H., Blankenship, P. D., Cole, R. J., \& Hill, R. A. (1984). Effect of soil temperature and drought on peanut pod and stem temperatures relative to Aspergillus flavus invasion and aflatoxin contamination. Mycopathologia, 86(1), 51-54.

Sant'Ana, A. S. (2010). Special issue on climate change and food science. Food Research International, 43(7), 1727-1728.

Santos, C., Paterson, R. R. M., Venâncio, A., \& Lima, N. (2010). Filamentous funga characterizations by matrix-assisted laser desorption/ionization time-of-flight mass spectrometry. Journal of Applied Microbiology, 108(2), 375-385.

Schaafsma, A. W., \& Hooker, D. C. (2007). Climatic models to predict occurrence of Fusarium toxins in wheat and maize. International Journal of Food Microbiology, 119(1-2), 116-125.

Schmitt, S. G., \& Hurburgh, C. R., Jr. (1989). Distribution and measurement of aflatoxin in 1983 Iowa corn. Cereal Chemistry, 66(3), 165-168.

Serra, R., Lourenço, A., Alípio, P., \& Venâncio, A. (2006). Influence of the region of origin on the mycobiota of grapes with emphasis on Aspergillus and Penicillium species. Mycological Research, 110(8), 971-978.

Serra, R., Mendonca, C., \& Venancio, A. (2006). Ochratoxin A occurrence and formation in Portuguese wine grapes at various stages of maturation. International Journal of Food Microbiology, 111, S35-S39.

Shaw, M. W., Bearchell, S. J., Fitt, B. D. L., \& Fraaije, B. A. (2008). Long-term relationships between environment and abundance in wheat of Phaeosphaeria nodorum and Mycosphaerella graminicola. The New Phytologist, 177(1), 229-238.

Shearer, J. F., Sweets, L. E., Baker, N. K., \& Tiffany, L. H. (1992). A study of Aspergillus flavus/parasiticus in Iowa crop fields - 1988-1990. Plant Disease, 76(1), 19-22.

Simpson, D. R., Thomsett, M. A., \& Nicholson, P. (2004). Competitive interactions between Microdochium nivale var. majus, M. nivale var. nivale and Fusarium culmorum in planta and in vitro. Environmental Microbiology, 6(1), 79-87.

Singh, B. K., Bardgett, R. D., Smith, P., \& Reay, D. S. (2010). Microorganisms and climate change: Terrestrial feedbacks and mitigation options. Nature Reviews Microbiology, 8(11), 779-790.

Speijers, G., Alink, G., de Saeger, S., Hardy, A., Magan, N., Pilegaard, K., et al. (2010). Evaluation of agronomic practices for mitigation of natural toxins report. ILSI Europe Process-Related Compounds and Natural Toxins Task Force 48 pp., Belgium ILSI Europe a.i.s.b.l.

Tassou, C. C., Natskoulis, P. I., Panagou, E. Z., Spiropoulos, A. E., \& Magan, N. (2007). Impact of water activity and temperature on growth and ochratoxin A production of two Aspergillus carbonarius isolates from wine grapes in Greece. Journal of Food Protection, 70(12), 2884-2888.

Tirado, M. C., Clarke, R., Jaykus, L. A., McQuatters-Gollop, A., \& Frank, J. M. (2010). Climate change and food safety: A review. Food Research International, 43(7), 1745-1765.

Tirado, M. C., Cohen, M. J., Aberman, N., Meerman, J., \& Thompson, B. (2010). Addressing the challenges of climate change and biofuel production for food and nutrition security. Food Research International, 43(7), 1729-1744.

Tjamos, S. E., Antoniou, P. P., \& Tjamos, E. C. (2006). Aspergillus spp., distribution, population composition and ochratoxin A production in wine producing vineyards in Greece. International Journal of Food Microbiology, 111, S61-S66.

van der Fels-Klerx, H. J., Kandhai, M. C., Brynestad, S., Dreyer, M., Börjesson, T., Martins, H. M., et al. (2009). Development of a European system for identification of emerging mycotoxins in wheat supply chains. World Mycotoxin Journal, 2(2), 119-127.

Varga, J., Koncz, Z., Kocsubé, S., Mátrai, T., Téren, J., Ostry, V., et al. (2007). Mycobiota of grapes collected in Hungarian and Czech vineyards in 2004. Acta Alimentaria, 36(3), 329-341.

Waalwijk, C., Kastelein, P., De Vries, I., Kerényi, Z., Van Der Lee, T., Hesselink, T., et al (2003). Major changes in Fusarium spp. in wheat in the Netherlands. European Journal of Plant Pathology, 109(7), 743-754.

Wallace, H. A. H., \& Sinha, R. N. (1981). Causal factors operative in distributional patterns and abundance of fungi: A multivariate study. In D. T. Wicklow, \& G. C. Carroll (Eds.), The fungal community - Its organisation and role in ecosystems (pp. 233-247). New York, USA: Marcell Dekker Inc.

Wilson, D. M., \& Payne, G. A. (1994). Factors affecting Aspergillus flavus group infection and aflatoxin contamination of crops. In D. L. Eaton, \& J. D. Groopman (Eds.), The toxicology of aflatoxins. Human health, veterinary, and agricultural significance (pp. 309-325). San Diego, CA: Academic Press.

Xu, X. M., Parry, D. M., Nicholson, P., Thomsett, M. A., Simpson, D., Edwards, S. G., et al. (2005). Predominance and association of pathogenic fungi causing Fusarium ear blight in wheat in four European countries. European Journal of Plant Pathology, 112(2), 143-154. 